\title{
Let's Hang on to What We've Got: Flexible Work Options and the Retention of Older Workers in Australia
}

\author{
Hélène Mountford ${ }^{1}$ \\ ${ }^{1}$ Department of Marketing and Management, Macquarie University, North Ryde, NSW 2109, Australia \\ Correspondence: Hélène Mountford, Department of Marketing and Management, Macquarie University, North Ryde, \\ NSW 2109, Australia. Tel: 61-0408-447-282. E-mail: helene.mountford@mq.edu.au
}

Received: November 22, 2013

Accepted: December 10, 2013

Online Published: December 12, 2013

doi: $10.5430 /$ bmr.v2n4p88

URL: http://dx.doi.org/10.5430/bmr.v2n4p88

\begin{abstract}
Governments in most developed countries are encouraging older workers to remain at work so as to reduce both social security liabilities and labour shortages. Research shows that older workers view flexible work options, which includes phased retirement and returns to work (recalls) as casuals or on contract, as a major incentive for remaining in the work force. There is little evidence employers are making these work conditions widely available. However, one industry with a high proportion of older workers, Aged Care Facilities (nursing homes), is using flexible work options as a major part of its labour retention strategy. These practices could be adapted to other industries.
\end{abstract}

Keywords: Retention, Older workers, Flexible work options, Phased retirement, Recalls

\section{Introduction}

Most developed countries have recognised that the ageing of the population through its greater longevity and lower fertility rates is leading to a reduced labour pool, although labour market demands are increasing. Never has the world's share of older people been as high (the share of those aged 60-plus now standing at about 11 per cent [760 million people] up from 8 per cent [200 million] in 1950) and projected to increase to 22 per cent ( 2 billion) by 2050 (Bloom, Sousa-Poza \& Sunde, 2013). The ageing trend and the decline in labour supply as the 'baby boomer' cohort retires, means organisations should be adapting their employment policies to attract and retain older workers. But while policy makers have for some time stressed the need to retain older staff, the working conditions which encourage older workers to stay in employment are often not available (Siegenthaler \& Brenner, 2001). Few employers have specific strategies in relation to age management (Abhayaratna, Andrews, Nuch \& Podbury, 2008; Cohen, Henkens \& Schippers, 2011; Szinovacz, 2011) and where they do, they are frequently not promoted, with employers preferring ad hoc individual arrangements (Harris, Foster \& Sempik, 2011; Kelly \& Kalev, 2006). Some authors have, particularly in the recent economic downturn, noted a decline in full-time employment and an increase in part-time work saying it indicates greater awareness of older worker needs. But this change can be attributed not to age/labour management or mutual agreement, but an organisation's desire to achieve numerical and functional flexibility (Sheridan \& Conway, 2001). Since the global financial crisis, research indicates that older workers have increased as a proportion of the total labour force, primarily due again to employers' needs to retain skills in preparation for an economic upturn (Beck, 2013; Mountford, 2011).

\subsection{Flexible work options}

Flexible work options (flexibility) are a recognised human resource management strategy for retaining older workers, and are viewed as a key retention or attraction factor by older employees (ABS, 2009; Oakman \& Howie, 2012; Walter \& Jackson, 2007; Watson, Manthorpe \& Andrews, 2003). Both the general human resource management literature and the nursing literature also recognise the use of flexible work options for increased commitment in older workers (Armstrong-Stassen \& Schlosser 2010; 2011); greater happiness engendering positive employee outcomes (Atkinson \& Hall, 2011); reduced nurse turnover (Mahoney, 2000); fewer sick days (Bloodworth, Lea, Lane \& Ginn, 2001); greater employee engagement, lower perceptions of work overload, better physical and mental health, and greater satisfaction with work-life balance (Pitt-Catsouphes, Matz-Costa \& Besen, 2009). Flexible work options contribute to staff resilience to the mental, physical and emotional demands of the work (Cameron and Brownie, 2010), staff retention, and reduced recruitment and training costs (Foster, 2007). 


\subsection{Australian ACFs}

Nursing homes, or aged care facilities (ACFs), operate 24/7 and provide long-term residential nursing care. In Australia, like most developed countries, aged care is a growing industry with a shortage of labour-demand for which as a share of the working population is set to increase by 140 per cent by 2050 as the population ages (OECD, 2011). In 2007 about 60 per cent of care staff in ACFs were aged more than 45 years compared with 37 per cent of the Australian workforce (Martin and King, 2008:15). While there has been some empirical research into direct care older workers, mainly nurses in hospitals and to a lesser extent community nurses, there has been little research on employee management in aged care facilities (Harley, Sargent \& Allen, 2010; Jeon, Glasgow, Merlyn \& Sansoni, 2010). This study is believed to be the first qualitative research into human resource practices in ACFs and finds that despite poor pay and what is seen as 'dirty work' (Adams \& Nelson, 2009), many ACFs are able to retain their staff for many years through a combination of flexible work, lack of age discrimination in hiring, modifications to work methods and equipment, and education, in a supportive workplace environment. This paper only examines the variety of 'flexibilities' offered in ACFs. Other supportive work practices are discussed elsewhere (Mountford, 2013).

\subsection{Flexibility criteria}

In a multi-generational study of more than 2000 people, Pitt-Catsouphes et al. (2009) categorised flexible work options into five major groups:

- The number of hours worked (including part-time, part year, job share, phased retirement and input into overtime),

- Flexible schedules (shift choices, changes in start or quitting times),

- Flexible place (location options, such as working from home),

- Options for time off (short or extended for personal reasons such as care responsibilities, study, volunteering), and

- Other options (such as control over timing of breaks, transferring to a job with reduced responsibility and pay).

As, by the very nature of the work, care in ACFs needs to be undertaken on the premises, the only workplace flexibility option not appropriate to this study is flexibility of place.

Specifically, the flexibilities here are divided into four groups:

- Choice of which and number of days worked (days),

- Choice of length of shift (hours),

- A supervisor's discretion to accommodate short-term changes, and

- Phased retirement and recalls to return.

These flexibility criteria are partly similar to Armstrong-Stassen \& Schlosser (2010) who used: the availability of flexible work schedules, part-time work, job sharing and unpaid leave options, which they developed for older nurses (in hospitals) as measures of work flexibility. As permanent part-time work dominates ACF employment, this negates the need for job sharing, and is not discussed here. The option of unpaid leave was not specifically included in this study, but from the comments of many Facility Managers (FMs) keeping jobs open for staff while they tended sick relatives, were unwell themselves, or needed to travel overseas, it is possible to conclude that unpaid, open-ended leave options are available. For example:

My night nurse, she went off and had both knees replaced and she was off for about five months. We just got someone else to fill her shifts, she came back and her hips went. So she's now had both hips and both knees replaced and she came back. FM Nicola, in aged care 24 years.

This paper describes the operations of the ACFs in this study before detailing a range of flexible work practices used for the attraction and retention of older workers.

\section{Method}

The study comprises interviews with 20 aged care Facility Managers (FMs) and 20 direct personal care workers (PCs), a total of 40 interviews, in Sydney, Australia's, northern, north western and inner city suburbs. They were selected at random using the Dunn \& Bradstreet Business Who's Who of Australia electronic data base and membership lists of industry associations, with no knowledge on the part of the author of whether they were for profit or not, or members of corporate chains. Semi-structured interviews of between one and 1.5 hours were conducted on site and were recorded, transcribed by a paid professional and themes determined using NVivo 9 software. Notes were also taken at the interviews. After the FM's interview, shorter interviews of about 30 to 40 minutes were conducted on site with a PC over the age of 45 years. (The Australian Bureau of Statistics has classified those aged 45 years and older as 'older 
workers', ABS, 2004.) These interviews were also recorded, transcribed and analysed. Afterwards web research was undertaken to establish more information about each of the ACFs. All but one had a web page. Other research from official sources such as the Federal Department of Health and Ageing, the Australian Institute of Health and Welfare and the Productivity Commission was also undertaken. The researcher did not review the many reports from these bodies nor the nursing home literature until after all interviews were completed and transcribed so as to ensure the research was undertaken with no prior knowledge or preconceptions of ACFs or their practices.

\subsection{Limitations}

This research was conducted in July and August 2010. Time and geographical constraints of the study limited its sample size, which influenced the data collected, so that the results may not be generalisable. However, the interviews obtained rich and in-depth data, reaching a point of saturation. Triangulation was achieved through separate interviews of FMs and PCs, and investigations of ACFs' web pages, government and industry associations' information and reports.

In this article when using quotations from the participants (whose names have been changed for anonymity) the amount of time the managers (FMs) had worked in aged care is included. The age of the personal carers (PCs) is included as they were interviewed as older workers.

\section{Results}

\subsection{The nursing homes}

Of the 20 nursing homes, 18 belonged to a group or chain. The two sole operators were set up for minority group residents (i.e. ethnic, low income). Ten were for profit (FP) and 10 were not-for-profit (NFP). Of the 10 NFP group, seven were part of large, well known religious charities. Of the $10 \mathrm{FP}$ homes, the size of the corporate group to which they belonged ranged from two to more than 60 nationally. The smaller homes were generally family-owned companies operating between two and six facilities. The largest corporation is owned by an investment section of a large public company. From an employee perspective, there is little difference between for profit or not-for-profit operations (King \& Martin, 2009).

\subsubsection{Bed numbers}

In Australia bed numbers are controlled by the Federal Government and residents for nursing home beds are classified as high or low care by an independent assessment team (Gargett, 2010). The government pays ACFs subsidies based on this classification.

The sizes of the institutions in this study ranged from 29 beds (an older establishment which still had some shared rooms) to 505 beds divided into a number of separate care-specific units on the same site. The average was 103, but by removing the outliers (above) which were not typical, the average number of beds was 86 . In the majority of homes, the occupancy rate was extremely high, generally close to 100 per cent, except when a bed was temporarily vacant after a resident's death, or if rooms were being refurbished. However, two homes in the study were not typical in that one was only recently opened and was taking time to fill up (another had taken 18 months to fill), while the other was not admitting new residents because it was due to close in a year's time and the beds would be transferred to a new ACF in the group. There was a mix of high, low and dementia specific beds. Three facilities offered only 'extra services', with luxury accommodation and foyers and public area decoration which resembled a five star hotel. They also offered a choice of menu and an onsite chef. (Nursing care is the same across all facilities.) Two others were built to provide extra services but were not granted the extra service beds by the government by the time of the interviews. Extra service beds are important to profitable operations as they allow the facility to charge bonds - essentially interest free loans for the length of the stay (Hogan, 2007). At the other end of the scale, two facilities accommodated low income residents and charged only the government subsidy which is covered by the state pension. The majority of nursing homes comprised a mix of beds for people with sufficient assets to pay bonds and/or accommodation charges and 'concessional' residents for whom only the government fee is charged. The age of the facilities ranged from eight weeks to 99 years although most of the older homes had been refurbished or extended in line with Federal Government requirements. In a number of cases new facilities were built and beds moved from a nearby old facility which was subsequently closed. Three of the facilities in the study had outsourced their catering, cleaning and laundry services, in a move to cut costs. The remainder continued to undertake these functions on site.

\subsection{Management}

The operations of ACFs are managed by an experienced Registered Nurse (RN) with the title of director of nursing, executive care manager or facility manager (FM), which is the generic title used here. 
Executive Care Manager, it means that you're encompassing more than just the care role, and it's a fairly new title in the last couple of years, I guess. Our role is still being developed and that is growing and growing in the scope of what we cover, more accountability to other areas, needing to know what the admission manager knows, needing to know what the chief financial officer knows, being part of all that. So we're all on a huge learning curve, it's very challenging. FM Liz, in aged care for 11 years.

The FMs are responsible for the day-to-day clinical and business operations, staffing and the implementation of human resource management policies from head office, but have considerable discretion. They are middle managers responsible to the owners, regional or corporate executives, or in the case of the two sole operations, directly to the board. They are expected to have hands-on accessibility, professional expertise in nurturing, recognition and team-building together with effective communication and flexibility (Jeon et al., 2010). Because of their broad discretion in day-to-day matters, how FMs manage their ACF has the potential of substantially affecting the morale of their workforce (Martin, 2007).

Each place is individual and the FM is the one who will employ the people to suit their facility. Attitudes, structure, size, it all impacts on - and even the type of residents that they have ... so the feel is different for each place. FM John, in aged care for 30 years.

Of the 20 FMs interviewed, 18 were women and two were men. FMs are experienced aged care RNs who move into management, often after being invited to take on more responsibility. They saw their principal role as supervising the provision of clinical care for residents although in the past decade there has been increased pressure for greater profitability.

There's so much more information around now about running places and you run them more as a business now. But the balance is trying to run it as a business and not forgetting that you've got residents here who treat this as their home and you have to meet that balance. There's a fine line between the two. FM Gail, in aged care for 17 years.

The trend for the future may be to separate responsibility for the clinical and business management roles.

I know another site (in this group) ... They are putting on a director of nursing and then they're having a business manager or site manager or centre manager or whatever you like to call it. There's very valid reasons for that, RNs are trained a specific way, they're not trained to make business decisions, they're trained to make clinical decisions and there is a big difference. I mean each residential aged care unit is a business. FM Marie, in aged care four months.

In this study the FMs' experience in aged care ranged from 32 years to four months. The average was 17 years. This was their amount of time in the residential aged care industry. Many had spent more years in general or community nursing before moving to aged care. Most 'came up through the ranks' having started in aged care as RNs, often working weekends or nights because they had young children who could be cared for by their partners at these times. Half had taken or were undertaking management courses.

\subsection{Direct care workers}

Most personal carers, particularly those interviewed who had been in aged care for a number of years, found the work profoundly satisfying. They were 'caring' people who found the relationships with residents an important factor in their lives. This was further indicated by the high number of carers who also spent additional time at the facility as volunteers (Watson, 2010). In addition to relationships with residents, carers also enjoy the friendships created with other staff and managers and the way the work is carried out (Moskos \& Martin, 2005). While facility turnover data was not available, all FMs acknowledged that lower turnover rates were among their older workers. Both FMs and direct care workers acknowledged that with increased length of employment, the latter were more able to select shifts to suit their work-life balance.

\subsubsection{Hours worked}

The majority of care staff work as permanent part-time (PPT) employees. In 2007, 70 per cent of PCs and 60 per cent of RNs were PPT workers (Martin \& King, 2008). In this study the average proportion of PPT care staff was 77 per cent, 10 per cent were full-time and 13 per cent were casual workers. In a number of ACFs the only full-time staff were the FM and the deputy FM, while in 11 of the 20 facilities, the PPT staff amounted to between 80 or 90 per cent of care staff. Generally FMs tried to keep a pool of casuals for when their regular staff were sick or as a trial role before offering PPT work.

\subsubsection{Age and gender}

The staff responsible to the FM comprise direct care workers (RNs, enrolled nurses and PCs, generically called nurses), catering, cleaning, laundry and maintenance employees, although direct care workers only are included in this study. 
The aged care industry with its high proportion of older workers, is unusual when compared with other industries. Watson (2010) found 90 per cent of ACF staff was female, many of whom were 'mature' with a considerable proportion being separated, or separated and raising children. In addition to the rigours of nursing work, life stressors for this female age group also included menopause, care for elderly parents, rearing teenagers, financial support for children in tertiary studies, grand-parenting, financial concerns for future retirement and/or single-parent and head of household responsibilities (Fitzgerald, 2007).

FMs were asked to estimate the proportion of their care staff which fitted in to six different age groups. In most cases the FMs did not estimate but utilised staff records to ascertain the information. As a result, the ACFs in this study had a total of 60 per cent of staff aged less than 45 years and 40 per cent above that age. Within the different age groups, the ranges were quite large, as shown in Table 1. For example, the facility with 51 per cent of PCs aged 45-54 also had another 27 per cent aged 55 and over (giving a total of 78 per cent older workers). The ACF with no staff aged more than 55 had only 10 per cent aged 45-54. However, this was the new facility which was building up the number of its permanent carers and the FM expected to employ more older staff.

Table 1. Proportion of employee age groups in ACFs in this study

\begin{tabular}{llll}
\hline Age range & Average $\%$ & Highest $\%$ & Lowest \% \\
\hline $15-24$ & 13 & 25 & 0 \\
$25-34$ & 26 & 50 & 7 \\
$35-44$ & 22 & 40 & 10 \\
$45-54$ & 24 & 51 & 10 \\
$55-64$ & 13 & 30 & 0 \\
$65+$ & 2 & 7 & 0
\end{tabular}

A 2007 national survey found 22.5 per cent of direct care workers were 55 or older (Jeon et al., 2010) compared with 16 per cent in this study. One explanation for the lower proportion of older workers here could be that most of the ACFs in this study employed a large number of international students on 20-hour a week work visas (aged about 20 to 30 years). International student labour (and migrant labour generally) is unlikely to be widely available outside major metropolitan areas, certainly not in the country where staff are older and more Anglo Saxon (Fragar and Depczynski, 2011). Nevertheless, few other industries operate with a significant proportion of their workers aged more than 45 years.

Of the 20 direct care staff interviewed, the average amount of time they had worked in aged care was nearly 16 years with a range of three years to 34 years. Their average age when they started working in aged care was almost 39 years old. The oldest age at which a PC started work in aged care was 57. The average age of PCs at the time of interview was 55 years, the oldest was 72 years and the youngest 45 years. Jackson and Walter (2010) found in their study of more than 2500 baby boomers that in the occupational code of Health and Welfare Associate Professionals (which includes but is not restricted to ACFs), 71 per cent expected to work beyond the age of 65 years. This was the highest proportion of any occupation.

\subsection{Age discrimination}

Generally older workers are discriminated against due to negative stereotyping by employers (Gringart, Helmes \& Speelman, 2011; Loretto \& White 2006; Taylor \& Walker, 1998), particularly women (Gringart et al., 2010), with some of the stereotypes being largely incorrect or outdated (Ng \& Feldman, 2010). Among scholars in the area, workplace age discrimination, particularly in recruitment, training and promotion, is recognised as a waste of valuable human resources (Posthuma \& Campion, 2009). In this study there was no evidence of negative age discrimination and some evidence of a preference for older workers. Most AFCs (13) employed staff over the age of 65 years, with the oldest care employee aged 75 years. Seven homes had care staff in their 70 s and eight others had carers aged between 65 and 70 years. Only five ACFs out of 20 had no care staff aged more than 65 years. Both FMs and PCs believed there was no age discrimination in the industry.

Interviewer: How long has the 75 year old been here?

Interviewee: She's been here for 13 years, (since) 1999.

Interviewer: That means that she was 62 when she came here? 
Interviewee: It's unreal isn't it? I mean certainly from a risk perspective it is something that you would be wary of, or be advised to be wary of. She's very passionate about what she does. FM Michael, in aged care for seven years.

Even when I was on the phone and rang up the FM about applying here, I said I've got all my documents, everything. I said there may be one problem for you, tell me now because I don't want to come all the way up there, I've got other places to go. She said, 'What's the problem Maree?' I said, I'm 57. She said, 'What's the problem, Maree?'. PC Maree, aged 61, when looking for her first job in aged care.

The recruitment of care staff appears to be based on an individual's attributes and capacities (as recommended by Brooke \& Taylor, 2005) such as health, level of English and experience.

We don't ask for age, there's no provision for the age to be written on the application form, so that's policy... at the end of the day I am looking for the experience that that person has and how they've dealt with that experience... how did they manage this situation or that situation, that's what it comes down to and if at the end you think, no, they did not answer the questions adequately, regardless of age, then they don't get the job. FM Louise, in aged care for 10 years.

The large proportion of ACF older employees was further supported in this study through FM preference for them because of their emotional maturity, life experience and patience.

In all honesty I'd rather hire people that have got more experience and emotional experience particularly, 'cos you're dealing with death and dying stuff all the time. FM Gail, in aged care 17 years.

Some researchers maintain employment of older workers is more likely when there are labour shortages (Karpinska, Henkens \& Schippers, 2011; London, 1992; Remery, Henkens, Schippers \& Ekamper, 2003) although a decade ago Hirsch, Macpherson and Hardy (2000) noted jobs with flex-time schedules, where part-time work was prevalent, had many older female workers and older hires. This study endorses that view.

\section{Flexible work}

Drawing on the Pitt-Catsouphes et al. (2002) criteria above, flexible work in ACFs is found in four different ways: the number and days of shifts (days); the length of shifts (hours); one-off changes as needed when other demands, particularly family, arise (supervisor flexibility); and phased retirement and recalls to work. These work options are important to both recruiting and retention.

\subsection{Attraction}

Two flexible work choices particularly attract employees to ACFs - the selection of which days to work (days) and the length of the shift (hours). Most direct care workers are employed permanent part-time (PPT). The flexibility of selecting their own regular shifts is a major attraction for care staff who are predominantly female and have family responsibilities, be they children, grandchildren or ageing relatives. Initially new PCs are asked to work a variety of shifts as casuals, but after they have established themselves as competent and reliable and become PPT, they can elect which days to work. ACFs are also attractive to RNs because the shifts can be chosen and are fixed, unlike hospitals where they are rotated.

We're very flexible with rostering, we recognise that most, probably 80 per cent of our staff are mothers and juggling families, and that family juggling doesn't stop when you get into your 50s, its grandkids then, most of them are looking after grandkids too, so the rostering is very flexible. FM Janice, in aged care for 22 years.

I was a little bit old I would say, you know, I was in my 40s when I finished training and I knew that working in a nursing home would give me the opportunity to do the shifts I want to do, so I could pick and choose the shifts that are most suitable. PC Crima, aged 52.

Because ACFs operate 24/7 there are many different shifts at different times of the day or night. Few nursing homes now operate the formerly standard three, eight-hour shifts a day and in this study while the average number of different shifts available to PCs was seven, one home operated 20 different shifts. The larger facilities offer a greater variety of shift lengths - eight, six or four hours. The shorter shifts particularly appeal to older workers.

Hours are often changed to try and get people in. If a shift becomes available, they may split it into two four-hour shifts, so that type of thing. FM John, in aged care for 30 years.

The shorter shifts also allow employer flexibility enabling extra staffing at peak times during the day.

I found that by making those shorter (six hour) shifts it gave me the flexibility to put extra staff on (at busy times) ... FM Jean, in aged care 32 years. 


\subsection{Retention}

Employee flexibility engenders loyalty and job satisfaction (Chou \& Robert, 2008). The opportunity to change regular shift days, or the length of a shift, or pick up an additional shift is widespread and important to retention (Moskos \& Martin, 2005). The need for change may be brought about by one-off occurrences or semi-permanent change.

In fact I'm always accommodating requests for changes, someone's Uni timetable suddenly changes and they need to change their days, or they can't get babysitting that day, or they're working another job ... FM Joy, in aged care nine years.

All PCs in this study confirmed the ease of changing or downsizing shifts either formally (with a form) or informally (verbal request). For example:

I was doing alternate afternoons and days and that was fine but as I got older when I came here I asked (the FM) if it was possible just to stay on days and she said that wasn't a problem... They'd do that for anyone here, but they like to listen especially (the FM) and she's very flexible. If something's wrong you just come and speak to her and if it's a valid reason, she'll do what she can. PC Amelia, aged 50 years.

\subsection{Supervisors' flexibility}

An important part of employee flexibility is the supervisor's attitude towards a worker's request to adjust work time for family needs (Katz, Lowenstein, Prilutzky \& Halperin, 2011). Research in hospitals has found immediate line managers play a crucial role in making flexible work available (Harris, Bennett, Davey \& Ross, 2010) and the relationship with the supervisor impacts firstly on the subordinate's morale, which then impacts on nurses' commitment to their institution (Brunetto, Farr-Wharton \& Shacklock 2010, 2011; Brunetto, Shriberg, Farr-Wharton, Shacklock, Newman \& Dienger, 2013) and well-being (Rodwell, Noblet, Demir \& Steane, 2009). This is especially so for women (Shacklock, Brunetto \& Nelson, 2009). Supervisor flexibility is common in aged care facilities, with emphasis on informal family friendly policies.

Staff know they can come and say, look I forgot little Johnny's concert's on tomorrow can I have the day off, they're encouraged to do that. It's easier for me to replace them during the day than they ring up at 4 o'clock in the morning and the night staff's trying to replace them. So we have very low sick leave. FM Nicola, in aged care 24 years.

The work flexibility culture appears industry wide and contributes to low sick leave and staff turnover, reduced costs for temporary agency staff, recruitment and training and greater retention, providing stability for the residents. All facilities in this study claimed low staff turnover and most claimed low sick leave. National annual staff turnover in 2007 was 25 per cent for PCs and 20 per cent for RNs (Martin \& King, 2008). FMs estimated international students on average stayed about two to three years, nursing students could work as PCs for up to seven years, then graduate, and PCs in the middle and older years were the long-term staff - 10 years plus. The longest serving PC interviewed in this study had been in aged care for 34 years, three others had worked in ACFs for 30 years and another 28 years.

A facility that I managed for seven and a half years, in the last three and a half years I had no resignations and hardly any sick leave. And before that, the first years, we probably had a turnover of about 20 per cent. FM Gail, in aged care for 17 years.

Avoiding the use of temporary agency staff (both RNs and PCs), which is expensive, also reduces sick leave and increases loyalty. Some FMs build up a pool of casual staff on which to draw when needed.

\section{Forms of retirement}

In business generally it is uncommon for employees and supervisors to discuss the former's retirement plans in advance (Henkens, 2005; Jackson, Walter \& Felmingham, 2006) making workforce planning difficult. Limited research on the topic has not provided a reason for this. Employers believe it is the worker's sole prerogative to raise the issue. Possibly it is not discussed because employees may feel insecure and believe they would be immediately replaced, or they may anticipate employers will not allow a change to part-time work. This research reflected the general literature with FMs waiting for direct care workers announcing their retirement. The PCs based this decision on a number of factors such as family demands, financial needs and their physical capabilities.

Retire? Probably (when) I'm 70. My husband keep saying when (their daughter) finish Year 12, how about you cut down ... because she's in (private school) - so expensive, so I have to work and work - tuition fee is high. PC Binongo, aged 59 .

Probably in a couple of years. Well I'm 72 now. Yes, I'll know when I need to retire. PC Ona, aged 72. 


\subsection{Phased retirement}

Phased retirement is another strongly desired option by older workers which is not always readily available (Armstrong-Stassen, 2005; Fitzgerald, 2007; Jackson \& Walter, 2010; Walter \& Jackson, 2007). But a 'phased withdrawal' from the labour market is wanted by a majority of older workers (Jackson \& Walter 2010; Walter \& Jackson, 2007) and HR policies should promote employees' control of their retirement decisions to facilitate retention (de Vaus, Wells, Kendig \& Quine, 2007). Every PC in this study thought they would determine their own retirement age, commonly in their $60 \mathrm{~s}$, but often at an indeterminate time when their health was inadequate to continue.

I'm not ready to give up work yet, I'm too young. I think if I gave up work I'd die, give me another 10 years maybe, 65,70 , until my body says no, I can't do it anymore. PC Carmen, aged 54.

All the PCs expected phased retirement in the form of reducing the number of shifts worked (days) and/or the length of their shifts (hours) before their retirement. They were aware this was common practice.

FMs accept 'winding down' as normal practice and accommodate PCs' schedules, usually reducing their days.

We're desperate to retain them because of their skill and their knowledge that we do whatever it takes to accommodate their needs and if it means they only want to work one day a week, then they only work one day a week. FM Janice, in aged care 22 years.

As with other organisations, most FMs do not know when staff intend to retire. The retirement conversation is usually initiated by the employee through an informal approach. Care staff often give FMs warning of retirement many weeks, months or years in advance. Rarely do they just give two weeks' notice. This allows FMs plenty of time to re-organise shifts and staffing.

I think the majority over the years, reduce work ... and it's not as if they would say 'by the way I'm retiring next week', it's like, 'look I'm probably only going to work for another 12 months', or 'you know I'm coming up for 65 I think I'll retire', something along those lines. They will give you warning, plenty of warning, so you can work around it. FM John, in aged care 30 years.

It is apparent that most staff have job security (also found by Martin [2007] in an earlier, different economic environment) and do not fear being replaced immediately if they give a long period of notice. FMs welcome lengthy notice as it allows for easier workforce planning and maintains morale. None of the FM interviewees would replace a direct care worker who had said they planned to retire, until they retired. They saw little point in replacing an experienced, competent worker with a new PC who would need training. Such a move would also affect morale.

Because 80 per cent of the staff have worked very closely together for a very long time, if you treat one staff member badly you lose the trust of all of them, and you just do yourself so much damage. And if you don't show as an organisation that you support your workers right till the end, then why should they provide any loyalty back to you. If you're not supporting them it's very public and if you're replacing somebody because they've put their hand up, why would the next person then give you adequate notice? FM Joan, in aged care 18 years.

A lengthy notice of retirement also provides the opportunity for staff to mentor others before they leave.

None of the ACFs had a fixed retirement age, nor formal retirement plans. Typical responses to the question, 'Do you have a common or fixed retirement age?' were:

No. We'd be up the creek if we did that. Really up the creek. FM Gail, in aged care 17 years.

No, we don't. My oldest staff member is 71. FM Sue, in aged care 20 years.

\subsection{Recalls}

Research indicates that many retired staff would welcome the opportunity to return to their work place, often on a casual or project basis. For example, Armstrong-Stassen (2005) found two thirds of RNs thought retirement with call back arrangements or phased retirement was 'highly important' to their decision to remain at work. Retired staff can be brought in for peak demand times or one off needs without the 'on boarding' costs of a temporary or contract worker because they know the culture and operating procedures of the organisation (Cappelli \& Novelli, 2010). As Shacklock, Fulop and Hort (2007) recommend, FMs here considered staff who were retiring as a future pool of employees. They actively encouraged retiring direct care workers to join the facility's casual list or try to find other useful positions or mentoring roles. 


\section{Discussion}

The older worker literature credits the availability of flexible work options as the primary attraction to stay at work longer. This study found that a number of different flexibilities both attracted and retained staff. As the industry has a large percentage of older workers, these flexible options allow them to juggle home and work commitments with reduced hours or days, and keep working longer or return to work. From this research it is evident that FMs want to retain these experienced staff and adjust their rosters wherever possible.

'Cos I was sick I spoke to (the FM) and said look I'd like to come back but if it's not a problem I'd like to come back for two days and she said, yeah, that's OK. Previously I was on three days. PC Yolanda, aged 57 years.

As is evident from the typical comment above, personal carers request changes in their work conditions when and where they think they need it and as a consequence do not seek work elsewhere. The availability of flexible work options is seen as industry wide and accepted as normal practice. It is a major reasons why staff continue to work in it.

\section{Conclusion}

This research sought to determine the human resource policies and practices aged care facilities utilise to retain older workers because it has a high proportion of older workers compared with other industries. In the main, the strategies are not part of formal policies but are common practices. This paper reports only on the flexible work options because it is the most important retention strategy (Australian Council of Trade Unions, 2011; Jackson \& Walter 2010; Watson, Manthorpe \& Andrews, 2003). Other retention strategies found in this research, such as a preference for a supportive workplace, modified work methods and equipment, appreciation, education and the opportunity to pass on knowledge, are discussed elsewhere (Mountford, 2013).

This study found direct care workers in ACFs are valued. Registered nurses are in short supply worldwide (Blake, 2010) and their retention is essential to western health care systems (Brunetto, Shriberg, Farr-Wharton, Shacklock, Newman \& Dienger, 2013; Buchan \& Seccombe, 2012). This research shows that there is at least one industry which is practising the work conditions that studies of older workers say that they want. Flexible work choice is the norm in ACFs. It is available in four different ways: the number and days of shifts (days); the length of shifts (hours); one-off changes as needed when other demands, particularly family, arise (supervisor flexibility); and phased retirement and recalls to work. As a consequence, the ACFs flexible work options meet all the Pitt-Catsouphes et al. (2009) criteria except flexibility of place. Obviously, this care work needs to be undertaken at the nursing home.

The need for employee-centred flexibility and control is a consistent theme for work-life balance in the nursing and mid-wife literature (Skinner, van Dijk, Elton \& Auer, 2011) where rotating rosters predominate. Flexibility in the residential aged care industry may be attributed to a number of factors. First, an established culture has developed in aged care which allows these conditions; second, the shortage of workers which allows them to demand the conditions they want; third, the predominance of female workers who need to juggle work and home responsibilities; and fourth, sympathetic supervisors/FMs, also predominantly female, who have had, or still have, a similar need to balance work and home priorities (see Katz et al., 2011). The female dominance of workers and supervisors is probably responsible for the workplace culture (Bloom, Kretschmer \& Van Reenen, 2011). These suggestions are conjecture drawn from this study and would benefit from further research.

Much older worker literature has, while encouraging workplace adaptation to the ageing workforce, stressed the need for workers not to be categorised or stereotyped by their chronological age but on their individual functional age. Aged care work gives all the appearance of doing this. During this study no FM could name any policies or practices designed solely for older workers. All policies and practices applied to all workers. Changes to practices or equipment, for example, were said to be undertaken for occupational health and safety reasons, not their ageing workforce, although it was their older staff who particularly benefitted. Flexible work options were available to and were used by all age groups whether it be for purposes of study, child care, other caring roles, voluntary work or pre-retirement. FMs' 'open door' policies are the norm and individual consultation with staff is common place, so that management is readily aware of, and accommodates, changing family situations. Universality of availability which provides optimum outcomes for all employees throughout the work-life cycle is said to be critical (Timmons, Hall, Fesko \& Migliore, 2011). Universality is also consistent with an FM's/supervisor's need to be seen to be 'fair' to all employees (Harris, Bennett, Davey \& Ross, 2010) which maintains the facility's morale. Despite all HRM policies and practices being available to all staff, they have particularly satisfied the needs of older workers as exemplified by their high level of retention. Other industries could benefit from adapting flexible work options which have proven so successful to nursing home staff retention. 


\section{Competing interests}

The author declares she has no competing interests.

\section{References}

Abhayaratna, J., Andrews, L., Nuch, H., \& Podbury, T. (2008). Part Time Employment: the Australian experience. Staff Working Paper. Canberra: Productivity Commission.

Adams, V., \& Nelson, J. (2009). The economics of nursing: articulating care. Feminist Economics, 15, 3-29. http://dx.doi.org/10.1080/13545700903153971

Armstrong-Stassen, M. \& Schlosser, F. (2010). When hospitals provide HR practices tailored to older nurses, will older nurses stay? It may depend on their supervisor. Human Resource Management Journal, 20, 375-390. http://dx.doi.org/10.1111/j.1748-8583.2010.00143.x

Armstrong-Stassen, M. \& Schlosser, F. (2011). Perceived organizational membership and the retention of older workers. Journal of Organizational Behavior, 32, 319-344. http://dx.doi.org/10.1002/job.647

Armstrong-Stassen, M. (2005). Human resource management strategies and the retention of older RNs. Nursing Leadership, 18, 50-66. http://dx.doi.org/10.12927/cjnl.2005.17036

Atkinson, C. \& Hall, L. (2011). Flexible working and happiness in the NHS. Employee Relations, 33, 88-105.

Australian Bureau of Statistics (2004). Australian Social Trends. Canberra: Australian Bureau of Statistics.

Australian Bureau of Statistics (2009). Australian Social Trends. Canberra: Australian Bureau of Statistics.

Australian Council of Trade Unions (2011). Voices from Working Australia: Findings from the ACTU Working Australia Census 2011. Melbourne: Australian Council of Trade Unions Working Paper 6/2011.

Beck, V. (2013). Employers' use of older workers in the recession. Employee Relations, 35, 257-271. http://dx.doi.org/10.1108/01425451311320468

Blake, N. (2010). Nursing migration: issues of equity and balance. People and Place, 18, 19-24.

Bloodworth, C., Lea, A., Lane, S. \& Ginn, R. (2001). Challenging the myth of the 12 hour shift: a pilot evaluation. Nursing Standard, 15, 33-6. http://dx.doi.org/10.7748/ns2001.04.15.29.33.c3006

Bloom, D., Sousa-Poza, A. \& Sunde, U. (2013). Co-editors' statement for the Journal of the Economics of Ageing. The Journal of the Economics of Ageing, 1, 1-2. http://dx.doi.org/10.1016/j.jeoa.2013.09.003

Bloom, N., Kretschmer, T. \& Van Reenen, J. (2011). Are family-friendly workplace practices a valuable firm resource? Strategic Management Journal, 32, 343-367. http://dx.doi.org/10.1002/smj.879

Brooke, L. \& Taylor, P. (2005). Older workers and employment: managing age relations. Ageing \& Society, 25, 415-429. http://dx.doi.org/10.1017/S0144686X05003466

Brunetto, Y., Farr-Wharton, R. \& Shacklock, K. (2010). The impact of supervisor-subordinate relationships on morale: implications for public and private sector nurses' commitment. Human Resource Management Journal, 20, 206-225. http://dx.doi.org/10.1111/j.1748-8583.2009.00117.x

Brunetto, Y., Farr-Wharton, R. \& Shacklock, K. (2011). Supervisor-nurse relationships, teamwork, role ambiguity and well being: public versus private sector nurses. Asia Pacific Journal of Human Resources, 49, 143-164. http://dx.doi.org/10.1177/1038411111400161

Brunetto, Y., Shriberg, A., Farr-Wharton, R., Shacklock, K., Newman, S. \& Dienger, J. (2013). The importance of supervisor-nurse relationships, teamwork, wellbeing, affective commitment and retention of North American Nurses. Journal of Nursing Management. http://dx.doi.org/10.1111/jonm.12111

Buchan, J. \& Seccombe, I. (2012). Using scenarios to assess the future supply of NHS nursing staff in England. Human Resources for Health, 10, 16. http://dx.doi.org/10.1186/1478-4491-10-16

Cameron, F. \& Brownie, S. (2010). Enhancing resilience in registered age care nurses. Australasian Journal on Ageing, 29, 66-71. http://dx.doi.org/10.1111/j.1741-6612.2009.00416.x

Cappelli, P. \& Novelli, B. (2010). Managing the older worker: How to prepare for the new organizational order. Boston: Harvard Business Press. 
Chou, R. \& Robert, S. (2008). Workplace support, role overload and job satisfaction of direct care workers in assisted living. Journal of Health and Social Behavior, 45, 208-222. http://dx.doi.org/10.1177/002214650804900207

Conen, W., Henkens, K., \& Schippers, J. (2011). Are Employers Changing Their Behavior Toward Older Workers? An Analysis of Employers' Surveys 2000-2009. Journal of Aging \& Social Policy, 23, 141-158. http://dx.doi.org/10.1080/08959420.2011.551612

de Vaus, D., Wells, Y., Kendig, H. \& Quine, S. (2007). Does gradual retirement have better outcomes than abrupt retirement? Results from and Australian panel study. Ageing \& Society, 27, 667-682. http://dx.doi.org/10.1017/S0144686X07006228

Fitzgerald, D. (2007). Aging, experienced nurses: their value and needs. Contemporary Nurse, 24, 237-242. http://dx.doi.org/10.5172/conu.2007.24.2.237

Foster, C. (2007). Craegmoor Healthcare: age diversity boosts recruitment and retention. Equal Opportunities Review, 162, 6-11.

Fragar, L. and Depczynski, J. (2011). Beyond 50. Challenges at work for older nurses and allied health workers in rural Australia: a thematic analysis of focus group discussions. BMC Health Services Research, 11,1-13. http://dx.doi.org/10.1186/1472-6963-11-42

Gargett, S. (2010). The introduction of a targeted user-pays approach to funding high-level residential aged care in Australia: an empirical investigation of the impact on price. Health Economics, Policy and Law, 5, 481-508. http://dx.doi.org/10.1017/S1744133109990314

Gringart, E., Helmes, E. \& Speelman, C. (2010). The Role of Stereotypes in Age Discrimination Hiring: Evaluation and Intervention. Saarbrucken, Germany: Lambert Academic Publishing AG.

Gringart, E., Helmes, E. \& Speelman, C. (2011). Development of a measure of stereotypical attitudes towards older workers. Australian Psychologist, 48, 110-118. http://dx.doi.org/10.1111/j.1742-9544.2011.00024.x

Harley, B., Sargent, L. \& Allen, B. (2010). Employee responses to 'high performance work system' practices: an empirical test of the disciplined worker thesis. Work, Employment and Society, 24,740-760. http://dx.doi.org/10.1177/0950017010380638

Harris, L., Foster, C., \& Sempik, A. (2011). Employers' policies for third age employment-the case for action and the rationale for reaction. In CIPD Conference, University of Keele. Retrieved December 9, 2013 from http://www.cipd.co.uk/NR/rdonlyres/7F7E4FA1-EB90-40F9-9A08-8614B94D091E/0/HarrisFosterandSempikr esearchpaperD.pdf

Harris, R., Bennett, J., Davey, B. \& Ross, F. (2010). Flexible working and the contribution of nurses in mid-life to the workforce: a qualitative study. International Journal of Nursing Studies, 47:418-426. http://dx.doi.org/10.1016/j.ijnurstu.2009.08.009

Henkens, K. (2005). Stereotyping older workers and retirement: the managers' point of view. Canadian Journal on Aging, 24, 353-366. http://dx.doi.org/10.1353/cja.2006.0011

Hirsch, B., Macpherson, D. \& Hardy, M. (2000). Occupational age structure and access for older workers. Industrial and Labor Relations Review, 53, 401- 418. http://dx.doi.org/10.2307/2695966

Hogan, W. (2007). The Organisation of Residential Aged Care for an Ageing Population. St Leonards, NSW: Centre for Independent Studies.

Jackson, N. \& Walter, M. (2010). Which of Australia's baby boomers expect to delay their retirement? An occupational overview. Australian Bulletin of Labour, 36, 29-83.

Jackson, N., Walter, M. \& Felmingham, B. (2006). Will Australia's Baby Boomers Change their Retirement Plans in Line with Government Thinking? Key points from ASRAM. Australian Survey of Retirement Attitudes and Motivations, Research Project 1. Hobart: University of Tasmania.

Jeon, Y-H., Glasgow, N., Merlyn, T. \& Sansoni, E. (2010). Policy options to improve leadership of middle manager in the Australian residential aged care setting: a narrative synthesis. BMC Health Services Research, 10 (190), 3-11.

Karpinska, K., Henkens, K. \& Schippers, J. (2011). The recruitment of early retirees: a vignette study of the factors that affect managers' decisions. Ageing \& Society, 31, 570-589. http://dx.doi.org/10.1017/S0144686X10001078 
Katz, R., Lowenstein, A., Prilutzky, D. \& Halperin, D. (2011). Employers' knowledge and attitudes regarding organizational policy toward workers caring for aging family members. Journal of Aging \& Social Policy, 23, 159-181. http://dx.doi.org/10.1080/08959420.2011.554120

Kelly, E., \& Kalev, A. (2006). Managing flexible work arrangements in US organizations: formalized discretion or 'a right to ask'. Socio-Economic Review, 4, 379-416. http://dx.doi.org/10.1093/ser/mw1001

King, D. \& Martin, B. (2009). Caring for profit? The impact of for-profit providers on the quality of employment in paid care. In Paid Care in Australia: Politics, Profits, Practices. Edited by King, D. \& Meagher, G. Sydney: Sydney University Press, 113-143.

London, M. (1992). When older workers are not expendable: organizational conditions associated with hiring and developing people over age 55. International Journal of Career Management, 4, 15-25. http://dx.doi.org/10.1108/09556219210014807

Loretto, W. \& White, P. (2006). Employers' attitudes, practices and policies towards older workers. Human Resource Management Journal, 16, 313-330. http://dx.doi.org/10.1111/j.1748-8583.2006.00013.x

Mahoney, C. (2000). Ward winners. People Management, 18, 537-567.

Martin, B. \& King, D. (2008). Who cares for older Australian? A picture of the residential and community based aged care workforce. Canberra: Department of Health and Ageing.

Martin, B. (2007). Good jobs, bad jobs? Understanding the quality of aged care jobs, and why it matters. Australian Journal of Social Issues, 42,183-197.

Moskos, M. \& Martin, B. (2005). What's Best, What's Worst? Direct Carers' Work in their Own Words. Adelaide: National Institute of Labour Studies.

Mountford, H. (2011). Oh won't you stay just a little bit longer: Changing employers' views of older workers. Australian Bulletin of Labour, 37, 164-190.

Mountford, H. (2013). I'll take care of you: the use of supportive work practices to retain older workers. Asia Pacific Journal of Human Resources, 51, 272-291. http://dx.doi.org/10.1111/j.1744-7941.2012.00048.x

Ng, T. \& Feldman, D. (2010). The relationships of age with job attitudes: A meta-analysis. Personnel Psychology, 63, 677-717. http://dx.doi.org/10.1111/j.1744-6570.2010.01184.x

Oakman, J., \& Howie, L. (2012). How can organisations influence their older employees' decision of when to retire? Work: A Journal of Prevention, Assessment and Rehabilitation, 45, 389-397.DOI 10.3233/WOR-2012-1403

OECD (2011). Help Wanted? Providing and Paying for Long-term Care. Paris: OECD.

Pitt-Catsouphes, M., Matz-Costa, C. and Besen, E. (2009). Workplace Flexibility: Findings from the Age \& Generations Study. Boston: The Sloan Center on Aging \& Work at Boston College.

Posthuma, R. \& Campion, M. (2009). Age stereotypes in the workplace: common stereotypes, moderators, and future research directions. Journal of Management, 35, 158-188. http://dx.doi.org/10.1177/0149206308318617

Remery, C., Henkens, K., Schippers, J. \& Ekamper, P. (2003). Managing an aging workforce and a tight labour market: views held by Dutch employers. Population Research and Policy Review, 22, 21-40. http://dx.doi.org/10.1023/A:1023543307473

Rodwell, J., Noblet, A., Demir, D. \& Steane, P. (2009). Supervisors are central to work characteristic affecting nurse outcomes. Journal of Nursing Scholarship, 41, 310-320. http://dx.doi.org/10.1111/j.1547-5069.2009.01285.x

Shacklock, K., Brunetto, Y, \& Nelson, S. (2009). The different variables that affect older males' and females' intentions to continue working. Asia Pacific Journal of Human Resources, 47, 79-101. http://dx.doi.org/10.1177/1038411108099291

Shacklock, K., Fulop, L. \& Hort, L. (2007). Managing older worker exit and re-entry practices: a 'revolving door'? Asia Pacific Journal of Human Resources, 45, 151-167. http://dx.doi.org/10.1177/1038411107073603

Sheridan, A., \& Conway, L. (2001). Workplace flexibility: reconciling the needs of employers and employees. Women in Management Review, 16, 5-11. http://dx.doi.org/10.1108/09649420110380238

Siegenthaler, J., \& Brenner, A. (2001). Flexible work schedules, older workers, and retirement. Journal of aging \& social policy, 12, 19-34. http://dx.doi.org/10.1300/J031v12n01_03 
Skinner, N., van Dijk, P., Elton, J. \& Auer, J. (2011). An in-depth study of Australian nurses' and midwives' work-life interaction. Asia Pacific Journal of Human Resources, 49, 213-232. http://dx.doi.org/10.1177/1038411111400263

Szinovacz, M. (2011). Introduction: The aging workforce: Challenges for societies, employers, and older workers. Journal of Aging \& Social Policy, 23, 95-100. http://dx.doi.org/10.1080/08959420.2011.555185

Taylor, P. \& Walker, A. (1998). Employers and older workers: attitudes and employment practices. Ageing \& Society, 18, 641-856. http://dx.doi.org/10.1017/S0144686X98007119

Timmons, J., Hall, A., Fesko, S. \& Migliore, A. (2011). Retaining the older workforce: social policy considerations for the universally designed workplace, Journal of Aging \& Social Policy, 23, 119-140. http://dx.doi.org/10.1080/08959420.2011.551623

Van Dalen, H., Henkens, K. \& Schippers, J. (2010). Productivity of older workers: perceptions of employers and

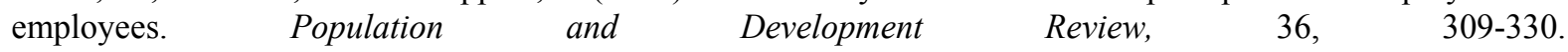
http://dx.doi.org/10.1111/j.1728-4457.2010.00331.x

Walter, M. \& Jackson, N. (2007). Baby Boomer Retirement Transition Preferences. Hobart: Australian Survey of Retirement Attitudes and Motivations, Research Project 5, University of Tasmania.

Watson, I. (2010). Low paid workers in the aged-care industry: Analysis based on Census and HILDA data. Research report for LHMU (Liquor, Hospitality and Miscellaneous Union). Retrieved 2 December 2013 from http://ww2.fwa.gov.au/manilafiles/files/s243/exhibitLHMU5.pdf

Watson, R., Manthorpe, J. \& Andrews, J (2003). Nurses over 50: Options, decisions and outcomes. Bristol : The Polity Press. 